\title{
Recurrent miscarriage in North Indian population: a study of association of polymorphisms in genes coding for the natural killer: cell receptor natural killer group 2 , member $D$ and its ligand MHC class I chain-related protein $\mathrm{A}$
}

\author{
Anup Rawool, Satyaprakash Gupta, Bharti Singh, Shubha R. Phadke, \\ Deepti Saxena, Kausik Mandal*
}

Department of Obstetrics and Gynecology, Medical Genetics, Sanjay Gandhi Post Graduate Institute of Medical Sciences, Raebareli Road, Lucknow, Uttar Pradesh, India

Received: 16 September 2019

Revised: 30 July 2020

Accepted: 03 August 2020

\section{*Correspondence:}

Dr. Kausik Mandal,

E-mail: mandal.kausik@gmail.com

Copyright: () the author(s), publisher and licensee Medip Academy. This is an open-access article distributed under the terms of the Creative Commons Attribution Non-Commercial License, which permits unrestricted non-commercial use, distribution, and reproduction in any medium, provided the original work is properly cited.

\section{ABSTRACT}

Background: The objective of this present study was to investigate the possible association of natural killer group (NKG) receptors gene polymorphisms and MHC class I chain-related protein A (MICA) gene polymorphism with recurrent spontaneous abortion (RSA).

Methods: Three single-nucleotide polymorphism (SNPs) in NKG2D gene (rs2255336, rs2617160 and rs2617170) and one SNP in MICA gene (MICA129) rs1051792 were assessed in 100 controls and 100 patients employing polymerase chain reaction-restriction fragment length polymorphism (PCR-RFLP) and agarose gel electrophoresis.

Results: NKG2D (rs2617160) and MICA 129 (rs1051792) variants are associated with RSA risk in North Indian women.

Conclusions: The NKG2D and MICA129 gene polymorphisms may influence the success of pregnancy in North Indian women population.

Keywords: MICA 129 gene, NKG2D gene, Single-nucleotide polymorphism, Unexplained recurrent spontaneous abortion

\section{INTRODUCTION}

Recurrent miscarriage $(\mathrm{RM})$ or recurrent spontaneous abortion (RSA) is usually defined as the loss of three or more consecutive pregnancies until the $20^{\text {th }}$ gestational week. Globally, 1-2\% of reproductive couples are affected by RSA. The causes of a miscarriage can be genetic, structural deformities of organs, hormonal, immunological, haematological, and/or environmental, but in about half the cases cause may not be found. ${ }^{1}$ NKG2D (Natural killer (NK) group 2, member D) is a $25,143 \mathrm{kDa}$ type II membrane protein comprising 216 amino acids, is an activating receptor expressed on NK and CD8 T cells and has been implicated in immunity against tumors and microbial pathogens. To exert cytotoxicity, major histocompatibility complex class I polypeptide-related sequence (MIC) molecules interact with the NKG2-D receptor and stimulate NK cells to release cytokines such as interferon- (IFN). KLRK1 gene (killer cell lectin-like receptor of the subfamily $\mathrm{K}$ member 1), on chromosome 12, encodes NKG2D, or CD314. The NK cells play an important role in the maintenance of pregnancy. Decidual NK cells produce a variety of cytokines contributing to uterine vascular remodeling. ${ }^{2}$ The maternal NK cells-mediated cytotoxicity limits the excessive trophoblast invasion 
during the formation of the placenta. Thus, any imbalance between the activation and the regulation system in NK cells will alter the homeostasis at the feto-maternal interface and the fetal allograft during pregnancy leading to a miscarriage. ${ }^{3}$ Negishi et al showed that NK cells (CD56dim CD16+NK cells) may play an important role in the onset of preterm labor. ${ }^{4}$ MICA molecules are found expressed in the human endometrium, on epithelial cells in secretory phase of menstrual cycle. ${ }^{5}$ MICA upregulation induces maternal rejection of fetus, in response to stresses of pregnancy such as hypoxia or aneuploidy. ${ }^{6}$ Expression of MICA molecules mRNA was detected in trophoblast and decidual cells, but no protein expression demonstrated, on implantation site at 8 weeks gestation cells from normal pregnancy. ${ }^{7}$

\section{METHODS}

This study was descriptive case control study. The study was conducted over a period of two years from January 2017 to December 2018.

The study group consisted of 100 North Indian women of reproductive age group diagnosed with RSA, who attended as outpatients in medical genetics, for genetic evaluation and counselling of recurrent spontaneous abortions. All patients had at least three pregnancy losses with unexplained etiology before $20^{\text {th }}$ week of gestation.

The control group consisted of 100 ethnically matched women (reproductive age group, no history of autoimmune disorder, no known personal or family history of RSA or other pregnancy complications) with at least one normal pregnancy and no spontaneous abortion, preterm labour, or preeclampsia.

\section{Inclusion criteria}

In woman of reproductive-age group, who had at least three pregnancy losses before $20^{\text {th }}$ week of gestation, the diagnosis of RSA was made.

\section{Exclusion criteria}

Any of the woman who matched any of the criteria as mentioned below was excluded from the study;

Chromosomal abnormalities of recurrent abortions in couple were excluded by karyotype of couple. Anatomic causes including intrauterine malformations, uterine fibroids and intrauterine adhesions (Asherman's syndrome) were excluded by pelvic examination and ultrasound. Hormonal causes such as hyperprolactinaemia, luteal insufficiency and hyperandrogenaemia were excluded. Autoimmune and thrombotic causes such as lupus and antiphospholipid antibody syndrome were excluded by evaluating lupus anticoagulant, anticardiolipin antibodies and anti-beta-2 glycoprotein. Medical causes such as thyroid disorders, diabetes mellitus, polycystic ovarian syndrome and systemic lupus erythematosus were excluded.

\section{Consent and sample collection}

Objectives of the study were explained to the couple and written informed consent was obtained from each individual for collection of clinical information and peripheral blood samples. Similar data collection procedures were used for patients and control subjects. Genetic study was performed on all patients and control subjects. Venous blood samples were collected in EDTAcontaining tubes.

\section{Laboratory methods}

\section{DNA extraction}

Genomic DNA extraction was done from EDTA blood using the QIAamp DNA blood mini kit (Qiagen) method. ${ }^{8}$

\section{Methodology for SNP analysis}

As NKG2D gene (rs2617160) and MICA 129 (rs1051792) harbored a restriction site hence analysis was performed by PCR-restriction fragment length polymorphism (RFLP) as per feasibility and cost effectiveness. While for SNP rs2617170 in NKG2D gene, there was no restriction site; so, detection was done by QRTPCR.

\section{SNP in NKG2D gene (rs: 2617170): T/A}

Genotyping was performed by a TaqMan 5-nuclease assay (applied biosystems) with allele specific fluorogenic oligonucleotide probes for NKG2D alleles, allowing to discriminating the genotypes of each studied pair of alleles.

Table 1: Itinerary for restriction digestion NKG2D gene (rs2617160). ${ }^{10}$

\begin{tabular}{|ll|}
\hline Restriction enzyme (ScaI) & $\mathbf{1 . 0}$ micro L (10 Unit) \\
\hline PCR product & 15.0 micro L \\
\hline 10X NE buffer & 2.5 micro L \\
\hline MQ & 6.5 micro L \\
\hline Total reaction volume & 25.0 micro L \\
\hline Incubation time & Overnight at $37^{\circ} \mathrm{C}$ \\
\hline
\end{tabular}

Genotyping was performed by the allelic discrimination method using VIC- and FAM-labelled primers. The reaction was performed in 20 microlitre (microL) as recommended by the manufacturer, 10 micro L Taq Man Universal master mix, $1 \mu \mathrm{L}$ FAM and VIC labelled primer, (Forward and Reverse) and 1 microL DNA. ${ }^{9}$ Thermal cycling was initiated with a 2 -min incubation at $50^{\circ} \mathrm{C}$, followed by a first denaturation step of $10 \mathrm{~min}$ at $95^{\circ} \mathrm{C}$, and then by 40 cycles of $15 \mathrm{~s}$ at $95^{\circ} \mathrm{C}$ and of $1 \mathrm{~min}$ 
at $60^{\circ} \mathrm{C}$. PCR plates were run and read in the ABI prism 7000 sequence detection system (applied biosystems). Results were analysed using the allelic discrimination software. ${ }^{10}$

\section{SNP in NKG2D gene (rs2617160): T/A}

SNP in NKG2D gene (rs2617160) was analysed using the polymerase chain reaction - restriction fragment length polymorphism (PCR-RFLP) method. The primers were as follows: 5' - GTCGTTAAAGGCATCGTTCC - 3' (forward) and 5' - GACTTAACACGCAGCCAACT - 3' (reverse) for the PCR of NKG2D. ${ }^{11}$

Table 2: Itinerary for restriction digestion MICA 129 (rs1051792). ${ }^{12}$

\begin{tabular}{|ll|}
\hline Restriction enzyme (Rsa) & $\mathbf{1 . 0}$ micro L (10 Unit) \\
\hline PCR product & 15.0 micro L \\
\hline 10X NE buffer & 2.5 micro L \\
\hline MQ & 6.5 micro L \\
\hline Total reaction volume & 25.0 micro L \\
\hline Incubation time & Overnight at $37^{\circ} \mathrm{C}$ \\
\hline
\end{tabular}

The PCR product of 1051 base pair was digested with ScaI restriction endonuclease (New England Biolab) at $37^{\circ} \mathrm{C}$ for overnight. The digested PCR products were analysed on $3 \%$ agarose gel electrophoresis for detection of SNP. Authors found TT homozygous wild type 1,051 bp, TA heterozygous mutant 1,051, 580 and $471 \mathrm{bp}$ and AA homozygous mutant 580 and $471 \mathrm{bp}$. The gel was stained with ethidium bromide and image was captured in geldoc where UV transilluminator visualized the bands. ${ }^{10}$

\section{MICA 129 genotyping (rs1051792): A/G = Met $/$ Val}

The MICA 129 polymorphism (rs1051792) was analysed using the polymerase chain reaction - restriction fragment length polymorphism (PCR-RFLP) method. The primers were as follows: 5' -CGTTCTTGTCCCTTTGCCC GTGTGC - 3' (forward; intron 1) and 5' -GATGCTG CCCCCATTCCCTTCCCAA - 3' (reverse; intron 5) for the first PCR, and 5' -GGGTCTGTGAGATCCATGA3(forward; exon 3) and 5' - TGAGCTCTGGAG GACTGGGTA-3' (reverse; exon 3) for the second PCR. The reverse primer for the second PCR step was modified to create a Rsa I recognition site, so that the MICA 129 Val sequence could be identified with Rsa I. ${ }^{12}$

Nested PCR products of MICA gene (122 bp) was digested with RsaI restriction endonuclease (New England Biolab) at $37{ }^{\circ} \mathrm{C}$ for overnight. The digested PCR products were analysed on $3 \%$ agarose gel electrophoresis for detection of SNP. Authors find in MICA-129 met/met wild type homozygous $127 \mathrm{bp}$, in MICA-129 met/val mutant type heterozygous 127, 104 and $23 \mathrm{bp}$ and in MICA-129 val/val mutant type homozygous $104 \mathrm{bp}$ and $23 \mathrm{bp}$ on gel. The gel was stained with Ethidium bromide and image was captured in geldoc where UV transilluminator visualized the bands.

\section{Statistical analysis}

Statistical analysis was performed on SPSS v.17.0 [13]. Pearson's chi-square test was used to assess intergroup significance (categorical variables). Gene polymorphisms were analysed for allelic frequency for both patients and controls.

\section{RESULTS}

\section{Patients and controls}

A total of hundred study subjects who had three or more miscarriages and hundred controls were included in the study.

Genetic polymorphisms three SNPs in NKG2D gene (rs2255336, rs2617160 and rs2617170) and one SNP in MICA gene (MICA129) rs: 1051792 taken for this study were assessed in 100 controls and 100 patients employing polymerase chain reaction-restriction fragment length polymorphism (PCR-RFLP) and agarose gel electrophoresis.

Table 3: Allele and genotypic frequencies of NKG2D gene (rs:2617170) T/A) in Indian population.

\begin{tabular}{|c|c|c|c|c|}
\hline & Patients & Controls & Odds ratio (95\% CI) & P-value \\
\hline Total women & $\mathrm{n}=\mathbf{1 0 0}$ (patients) & $\mathrm{n}=\mathbf{1 0 0}$ (control) & & \\
\hline \multicolumn{5}{|c|}{ Allele frequency (total number of alleles) } \\
\hline $\mathrm{C}$ & $0.52(105)$ & $0.54(108)$ & 1.0 (reference) & \\
\hline $\mathrm{T}$ & $0.48(95)$ & $0.46(92)$ & $0.598(0.31-1.138)$ & 0.764 \\
\hline \multicolumn{5}{|c|}{ Genotypic frequency (total number of genotypes) } \\
\hline $\mathrm{C} / \mathrm{C}$ & $0.35(35)$ & $0.26(26)$ & 1.0 (reference) & \\
\hline $\mathrm{C} / \mathrm{T}$ & $0.45(45)$ & $0.56(56)$ & $0.598(0.312-1.138)$ & 0.118 \\
\hline $\mathrm{T} / \mathrm{T}$ & $0.20(20)$ & $0.18(18)$ & $0.827(0.362-1.885)$ & 0.65 \\
\hline $\mathrm{C} / \mathrm{T}+\mathrm{T} / \mathrm{T}$ & $0.65(65)$ & $0.74(74)$ & $0.653(0.353-1.201)$ & 0.171 \\
\hline
\end{tabular}


One SNP in NKG2D gene (rs2617170) were assessed by allelic discrimination (real-time PCR) in both patients and control women. In this study authors investigated the possible association of natural killer group (NKG) receptors gene polymorphisms and MHC class I chainrelated protein A (MICA) gene polymorphism with RSA.

\section{Allelic and genotypic frequency $C / T$ in NKG2D gene (rs: 2617170)}

NKG2D gene (rs: 2617170) polymorphism [OD ratio for carriers of the $\mathrm{T}$ allele $=0.598 ; 95 \% ; \mathrm{CI}=(0.31-1.138), \mathrm{p}$ value; 0.764 and $\mathrm{OD}$ ratio for carriers of the $\mathrm{C} / \mathrm{T}$ allele $=$ $0.598 ; 95 \%$; $\mathrm{CI}=(0.312-1.138), \mathrm{p}$ value; 0.118$]$. The OD ratio for combined homozygous mutant (TT) and heterozygous mutant type $\mathrm{C} / \mathrm{T}$ with reference to homozygous $\mathrm{C} / \mathrm{C}$ is $0.653,95 \% \mathrm{CI}=(0.353-1.201)$ and $\mathrm{p}$ value of 0.171 . The findings did not exhibit statistically significant association with RSA in females and controls in North Indian population (Table 3).

\section{Allelic and genotypic frequency T/A in NKG2D gene (rs2617160)}

In this study authors found that NKG2D gene (rs2617160) carrier T/A heterozygous polymorphism [(OD ratio for carriers of the T/A allele $=2.342 ; 95 \%$; CI $=(1.27-4.35), \mathrm{p}$ value; 0.006] showed significant association with RSA risk in Indian female population (Table 4). Homozygous A/A polymorphism [(OD ratio for carriers of the A/A allele $=2.694 ; 95 \%$; $\mathrm{CI}=(1.084$ 6.917), p value; 0.032] was significantly associated with disease. Also, there is significant association in combined heterozygous mutant and homozygous mutant $(\mathrm{T} / \mathrm{A}+\mathrm{A} / \mathrm{A})$ with OD ratio $2.418(95 \% \mathrm{CI}=(1.35-4.35)$ and $\mathrm{p}$ value is 0.002 (Table 4). This confirmed that homozygous A/A, heterozygous T/A and combined heterozygous T/A and homozygous mutant A/A were significantly associated with RSA risk in North Indian population.

Table 4: Allele and genotypic frequencies of NKG2D gene (rs2617160) T/A) in Indian population.

\begin{tabular}{|c|c|c|c|c|}
\hline & Patients & Controls & Odds ratio $(95 \% \mathrm{CI})$ & P-value \\
\hline Total women & $\mathrm{n}=\mathbf{1 0 0}$ (patients) & $\mathrm{n}=\mathbf{1 0 0}$ (controls) & & \\
\hline \multicolumn{5}{|c|}{ Allele frequency (total number of alleles) } \\
\hline $\mathrm{T}$ & $0.57(114)$ & $0.64(141)$ & 1.0 (reference) & \\
\hline A & $0.43(86)$ & $0.36(59)$ & $1.8(1.192-2.73)$ & 0.0051 \\
\hline \multicolumn{5}{|c|}{ Genotypic frequency (total number of genotypes) } \\
\hline $\mathrm{T} / \mathrm{T}$ & $0.28(30)$ & $0.45(51)$ & 1.0 (reference) & \\
\hline T/A & $0.58(54)$ & $0.39(39)$ & $2.342(1.27-4.35)$ & 0.006 \\
\hline $\mathrm{A} / \mathrm{A}$ & $0.14(16)$ & $0.16(10)$ & $2.694(1.084-6.917)$ & 0.032 \\
\hline $\mathrm{T} / \mathrm{A}+\mathrm{A} / \mathrm{A}$ & $0.71(70)$ & $0.55(49)$ & $2.418(1.35-4.35)$ & 0.002 \\
\hline
\end{tabular}

Table 5: Allele and genotypic frequencies of MICA 129 polymorphism (rs1051792) A/G) in North Indian population.

\begin{tabular}{|c|c|c|c|c|}
\hline & Patients & Controls & Odds ratio (95\% CI) & P-value \\
\hline Total women & $\mathrm{n}=\mathbf{1 0 0}$ (patients) & $\mathrm{n}=100($ controls $)$ & & \\
\hline \multicolumn{5}{|c|}{ Allele frequency (total number of alleles) } \\
\hline A & $0.5(101)$ & $0.63(126)$ & 1.0 (reference) & \\
\hline G & $0.5(99)$ & $0.37(74)$ & $1.667(1.119-2.49)$ & 0.011 \\
\hline \multicolumn{5}{|c|}{ Genotypic frequency (total number of genotypes) } \\
\hline $\mathrm{A} / \mathrm{A}$ & $0.26(26)$ & $0.44(44)$ & 1.0 (reference) & \\
\hline $\mathrm{A} / \mathrm{G}$ & $0.49(49)$ & $0.38(38)$ & $2.171(1.142-4.17)$ & 0.017 \\
\hline $\mathrm{G} / \mathrm{G}$ & $0.25(25)$ & $0.18(18)$ & $2.593(1.056-6.522)$ & 0.032 \\
\hline $\mathrm{A} / \mathrm{G}+\mathrm{G} / \mathrm{G}$ & $0.74(74)$ & $0.56(56)$ & $2.227(1.229-4.08)$ & 0.008 \\
\hline
\end{tabular}

\section{Allelic and genotypic frequency $A / G$ in MICA 129 genotyping (rs1051792)}

MICA 129 (rs1051792) carrier A/G heterozygous polymorphism $[(\mathrm{OD}$ ratio for carriers of the $\mathrm{A} / \mathrm{G}$ allele $=$ $2.171 ; 95 \%$; $\mathrm{CI}=((1.142-4.17), \mathrm{p}$ value; 0.017$]$ showed significant association with RSA risk in North Indian female population (Table 5). Authors calculated the OD ratio and $p$ value for homozygous $\mathrm{G} / \mathrm{G}$ mutant genotype and found significant association with RSA, G/G homozygous polymorphism [(OD ratio for carriers of the $\mathrm{G} / \mathrm{G}$ allele $=2.593 ; 95 \% ; \mathrm{CI}=(1.056-6.522), \mathrm{p}$ value; 0.032]. Also, there was significant association in combined heterozygous mutant and homozygous mutant 
$(\mathrm{A} / \mathrm{G}+\mathrm{G} / \mathrm{G}) . \mathrm{A} / \mathrm{G}$ and $\mathrm{G} / \mathrm{G}$ has $\mathrm{OD}$ ratio $2.227,95 \% \mathrm{CI}=$ (1.229-4.08) and $\mathrm{p}$ value is 0.008 (Table 5). This confirmed that homozygous mutant $\mathrm{G} / \mathrm{G}$, heterozygous mutant $\mathrm{A} / \mathrm{G}$ and combined $(\mathrm{G} / \mathrm{G}$ and $\mathrm{A} / \mathrm{G})$ were significantly associated with RSA risk in North Indian population (Table 5).

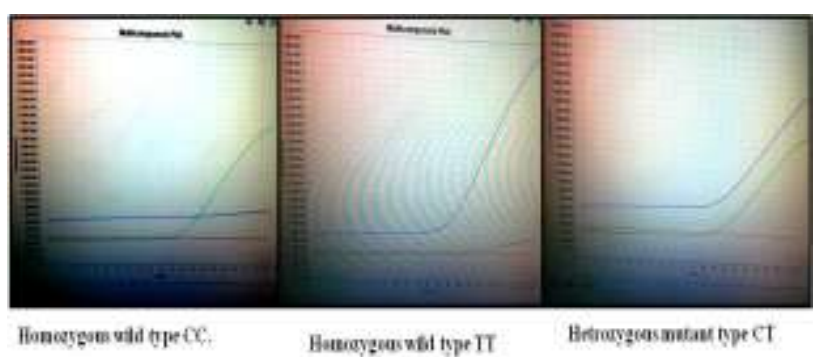

Figure 1: Allele discrimination on the basis of amplification plot (Vic and Fam).

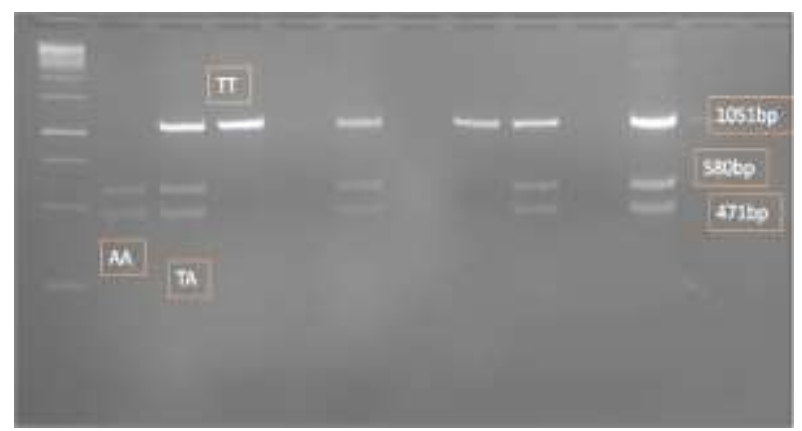

Figure 2: Detection of SNP in NKG2D (rs2617160) in $2 \%$ agarose gel.

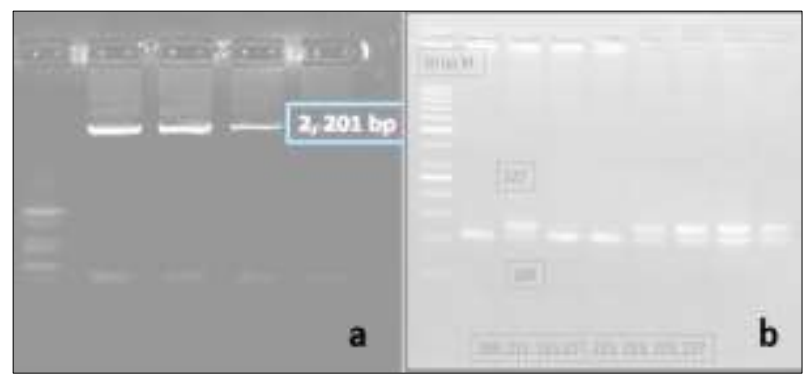

Figure 3: a) Detection of first PCR product (2201 bp), b) Detection of digested nested PCR product with Rsa I on $3 \%$ agarose gel.

\section{DISCUSSION}

Various causes have been implicated in the etiopathogenesis of RSA, apart from immunological factors, Genetic polymorphisms in various genes is a subject of research. Rad et al found increased NK cells in the peripheral blood of women with recurrent miscarriages. ${ }^{14}$ NKG2D plays an important role through cytotoxicity and cytokine release in the pathogenesis of infections, autoimmune diseases, and GVHD. ${ }^{15-17}$
Hayashi et al, and Espinoza et al found association between NKG2D haplotype and phenotype (high or low natural cytotoxic activity) in the occurrence of cancer and the transplants outcomes. rs2617160 and rs2617170, were significantly associated with reduced risk of cancer and better clinical outcome after transplantation. ${ }^{18,19}$ In the Tunisiancohort of Hizem et al T/T genotype in SNP rs2617170 was associated with a higher cytotoxic activity and a decreased risk of cancer development, while it was associated with successful pregnancy. ${ }^{10}$ Authors found there was no statistically significant association of NKG2D gene (rs: 2617170) polymorphism in RSA in females and controls in North Indian population. This was in contrast to Hizem et al who found significant difference in mean allele frequency (MAF) of NKG2D 11 (rs2617170) between patients and controls $(p=0.04)$ that translated into a low protective effect against RSA in the Tunisian population [OR $(95 \%)=0.79(0.64-0.99)] .{ }^{10}$ This could be due to ethnicity, environmental factors or modifier effect of other variants.

Various studies have shown that TT genotype in rs2617160 is associated with increased risk of SLE and chronic hepatitis $\mathrm{B}$ due to high cytotoxic activity. ${ }^{20,21}$ Authors found that NKG2D gene (rs2617160) carrier T/A heterozygous polymorphism [(OD ratio for carriers of the $\mathrm{T} / \mathrm{A}$ allele $=2.342 ; 95 \% ; \mathrm{CI}=(1.27-4.35), \mathrm{p}$ value; 0.006] showed significant association with RSA risk in north Indian female population which could as well be due to immunomodulation effect of the heterozygous T/A genotype.

This MICA-129 polymorphism (rs1051792) has been associated with a number of diseases such as ankylosing spondylitis, cancer, and chronic graft-versus-host disease (cGVHD). ${ }^{22-24}$ It was suggested that a potential cytotoxic attack by maternal NK was the down-regulation of the activating NK-cell receptor NKG2D by the soluble MIC molecules (sMICA) which results from the proteolytic shedding of the membrane-bound molecules by placental exosomes. ${ }^{25,26}$ While authors found MICA 129 (rs1051792) carrier A/G heterozygous polymorphism $[(\mathrm{OD}$ ratio for carriers of the $\mathrm{A} / \mathrm{G}$ allele $=2.171 ; 95 \%$; CI $=(1.142-4.17), \mathrm{p}$ value; 0.017] showed significant association with RSA risk in North Indian female population. Linsingen et al in their study found, MICA $129 \mathrm{Met} / \mathrm{Val}$ dimorphism in mother and sMICA plasma levels did not differ between cases and controls and that MICA-129Val/Val genotype was associated with higher sMICA plasma levels. ${ }^{27}$ While Hizem et al found no significant association with RSA for MICA-129 $\left(\right.$ rs1051792)..$^{10}$

To the best of authors knowledge this is the first such study to be reported from the north Indian female population. The contrasting results in this study as compared to Tunisian population Hizem et al could be explained due to modifier effect of variants in other genes influencing the cytokine release, cytotoxicity and 
immunomodulation, however study on a larger Indian cohort is required.

\section{CONCLUSION}

In conclusion, this study data supports an effect of the NKG2D (rs2617160) and MICA 129 (rs1051792) variants on RSA risk in North Indian women. This association of NKG2D and MICA 129 genetic variants to RSA risk should be viewed in context of the cytokine environment in pregnancy along with modifier effects of other polymorphisms in NKG2D and other genes. Further studies on a larger population are needed to confirm the current findings and to reveal the underlying mechanism by which NKG2D polymorphisms influence overall RSA risk.

\section{ACKNOWLEDGMENTS}

Authors would like to thank women who enrolled for this study.

Funding: The study funding from the Indian Council of Medical Research, Government of India, New Delhi, India (grant number 63/8/2010-BMS)

Conflict of interest: None declared

Ethical approval: The study was approved by the Institutional Ethics Committee

\section{REFERENCES}

1. Branch DW, Gibson M, Silver RM. Recurrent miscarriage. N Engl J Med. 2010;363:1740-7.

2. Hanna J, Goldman-Wohl D, Hamani Y, Avraham I, Greenfield C, Natanson-Yaron S, et al. Decidual NK cells regulate key developmental processes at the human fetal-maternal interface. Nat Med. 2006;12(9):1065-74.

3. Shigeru S, Akitoshi N, Subaru MH, Shiozaki A. The balance between cytotoxic NK cells and regulatory NK cells in human pregnancy. J Reprod Immunol. 2008;77(1):14-22.

4. Negishi Y, Shima Y, Takeshita T, Takahashi H. Distribution of invariant natural killer $\mathrm{T}$ cells and dendritic cells in late pre-term birth without acute chorioamnionitis. Am J Reproduct Immunol. 2017;77(6):e12658.

5. Basu S, Pioli PA, Conejo-Garcia J, Wira CR, Sentman CL. Estradiol regulates MICA expression in human endometrial cells. Clin Immunol. 2008;129(2):325-32.

6. Weier JF, Weier HU, Jung CJ, Gormley M, Zhou Y, Chu LW, et al. Human cytotrophoblasts acquire aneuploidies as they differentiate to an invasive phenotype. Develop Biol. 2005;279(2):420-32.

7. Apps R, Gardner L, Traherne J, Male V, Moffett A. Natural-killer cell ligands at the maternal-fetal interface: UL-16 binding proteins, MHC class-I chain related molecules, HLA-F and CD48. Human Reproduct. 2008;23(11):2535-48.
8. QIAGEN USA. Available

at:

https://www.qiagen.com/us/shop/sample-

technologies/dna/genomic-dna/qiaamp-dna-blood-

mini-kit/\#orderinginformation. Accessed on $8^{\text {th }}$ June 2019.

9. Applied Biosystems, Villebon-sur-Yvette, France. Available at: https://www.thermofisher.com/in/en/home/brands/ap plied-biosystems.html. Accessed on $4^{\text {th }}$ June 2019.

10. Hizem S, Mtiraoui N, Massaoudi S, Fortier C, Boukouaci W, Kahina A, et al. Polymorphisms in genes coding for the NK-cell receptor NKG 2D and its ligand MICA in recurrent miscarriage. Am $\mathrm{J}$ ReprodImmunol. 2014;72(6):577-85.

11. Ma J, Guo X, Wu X, Li J, Zhu X, Li Z, et al. Association of NKG2D genetic polymorphism with susceptibility to chronic hepatitis B in a Han Chinese population. J Med Virol. 2010;82(9):1501-7.

12. Yoshida K, Komai K, Shiozawa K, Mashida A, Horiuchi T, Tanaka Y, et al. Role of the MICA polymorphism in systemic lupus erythematosus. Arth Rheumat. 2011;63(10):3058-66.

13. IBM Corp. IBM SPSS Statistics for Windows, Version 24.0. Armonk, NY: IBM Corp. Available at: https://www-

01.ibm.com/support/docview.wss?uid=swg21476197 . Accessed on $10^{\text {th }}$ June 2019.

14. Rad HA, Basirat Z, Mostafazadeh A, Faramarzi M, Bijani A, Nouri HR, et al. Evaluation of peripheral blood NK cell subsets and cytokines in unexplained recurrent miscarriage. J Chinese Med Associat. 2018;81(12):1065-70.

15. Park KS, Park JH, Song YW. Inhibitory NKG2A and activating NKG2D and NKG2C natural killer cell receptor genes: susceptibility for rheumatoid arthritis. Tissue Antigens. 2008;72(4):342-6.

16. Kabalak G, Thomas RM, Martin J, Ortego-Centeno $\mathrm{N}$, Jimenez-Alonso J, de Ramón E, et al. Association of an NKG2D gene variant with systemic lupus erythematosus in two populations. Hum Immunol. 2010;71(1):74-8.

17. Zingoni A, Ardolino M, Santoni A, Cerboni C. NKG2D and DNAM-1 activating receptors and their ligands in NK-T cell interactions: role in the NK cell-mediated negative regulation of $\mathrm{T}$ cell responses. Front Immunol. 2013;3:408.

18. Hayashi $T$, Imai $K$, Morishita $Y$, Hayashi I, Kusunoki Y, Nakachi K. Identification of the NKG2D haplotypes associated with natural cytotoxic activity of peripheral blood lymphocytes and cancer immunosurveillance. Cancer Res. 2006;66(1):56370.

19. Espinoza JL, Takami A, Onizuka M, Sao H, Akiyama H, Miyamura $\mathrm{K}$, et al. NKG2D gene polymorphism has a significant impact on transplant outcomes after HLA-fully-matched unrelated bone marrow transplantation for standard risk hematologic malignancies. Haematol. 2009;94(10):1427-34.

20. Kabalak G, Thomas RM, Martin J, Ortego-Centeno $\mathrm{N}$, Jimenez-Alonso J, de Ramón E, et al. Association 
of an NKG2D gene variant with systemic lupus erythematosus in two populations. Human Immunol. 2010;71(1):74-8.

21. Ma J, Guo X, Wu X, Li J, Zhu X, Li Z, et al. Association of NKG2D genetic polymorphism with susceptibility to chronic hepatitis B in a Han Chinese population. J Med Virol. 2010;82(9):1501-7.

22. Amroun H, Djoudi H, Busson M, Allat R, El Sherbini SM, Sloma I, et al. Early-onset ankylosing spondylitis is associated with a functional MICA polymorphism. Human Immunol. 2005;66(10):105761.

23. Douik H, Chaaben AB, Romdhane NA, Romdhane HB, Mamoghli T, Fortier C, et al. Association of MICA-129 polymorphism with nasopharyngeal cancer risk in a Tunisian population. Human Immunol. 2009;70(1):45-8.

24. Boukouaci W, Busson M, Peffault de Latour R, Rocha V, Suberbielle C, Bengoufa D, et al. MICA129 genotype, soluble MICA, and anti-MICA antibodies as biomarkers of chronic graft-versus-host disease. Blood J Am Society Hematol. 2009;114(25):5216-24.

25. Porcu-Buisson G, Lambert M, Lyonnet L, Loundou A, Gamerre M, et al. Soluble MHC Class I chainrelated molecule serum levels are predictive markers of implantation failure and successful term pregnancies following IVF. Human Reprod. 2007;22(8):2261-6.

26. Choy MK, Phipps ME. MICA polymorphism: biology and importance in immunity and disease. Trends Mol Med. 2010;16(3):97-106.

27. Von Linsingen R, Gelmini GF, da Graça Bicalho M, De Carvalho NS. MICA-129 A/G dimorphism, its relation to soluble mica plasma level and spontaneous preterm birth: a case-control study. Jo Reprod Immunol. 2018;129:9-14.

Cite this article as: Rawool A, Gupta S, Singh B, Phadke SR, Saxena D, Mandal K. Recurrent miscarriage in North Indian population: a study of association of polymorphisms in genes coding for the natural killer: cell receptor natural killer group 2, member D and its ligand MHC class I chain-related protein A. Int J Reprod Contracept Obstet Gynecol 2020;9:3665-71. 